\title{
Art Design Specialty Teaching Reform based on the Practice Skills Contest Platform
}

\author{
Yimei Jiang \\ Zhengzhou University of Industrial Technology, Zhengzhou 451150, China
}

Keywords: Art design, teaching reform, practice skills contest.

\begin{abstract}
Art design practice skills competition is important carrier of cultivating the ability of practical application to encourage, promote and practice for students majoring in art design class. Based on the platform of the testing standard, in order to improve the students' creative thinking ability and to innovate practical ability, colleges and universities is very necessary to introduce the competition mechanism to the reform of teaching, in order to realize the of art design engineering applied talents training target which to promote "contest promote learning" mode of teaching reform and promote the "four changes" in the teaching reform.
\end{abstract}

\section{Introduction}

With the development of the society, the social demand for talents in the unceasing change, applied talents become synonymous with a 21st century talented person demand step by step, especially in the field of art design, knowledge and ability. Creativity and practice with the high level of art design creative talents was widely welcomed. However, art design company companies between art and design professional graduates "employment" such as "talented person" and the contradiction. Let us recognize that the current situation of art design specialty talents with the goal of market demand, then there are certain gap, majoring in art design teaching present situation is not optimistic, students' application ability training needs to be strengthened. At present, the conveyor is suitable for the need of society and applied art designer for the society that is an important task faced by colleges and universities, also an important task, and promote the reform of teaching. The higher art education has become the important content and urgent task.

\section{Organization of Art Design Practice Skills Contest}

At present, creative competition held by professional practice skills contest in addition to the university campus design exhibition, the art design specialty is also operating skilled professional practice skills outside platform, more organized by education institutions or industry association as shown in table 1.

Table 1 Art design major practical skills competition schedule

\begin{tabular}{|c|c|c|c|c|}
\hline Contest name & The organizer & $\begin{array}{l}\text { The main } \\
\text { object of } \\
\text { competition }\end{array}$ & Level & Note \\
\hline $\begin{array}{l}\text { "Star of henan" } \\
\text { design art } \\
\text { competition }\end{array}$ & $\begin{array}{l}\text { The education } \\
\text { department of henan } \\
\text { province, henan } \\
\text { province development } \\
\text { and reform commission, } \\
\text { the cultural department } \\
\text { of henan province }\end{array}$ & $\begin{array}{l}\text { The school } \\
\text { teachers and } \\
\text { students, } \\
\text { design unit, } \\
\text { etc }\end{array}$ & $\begin{array}{l}\text { Provincial } \\
\text { departmental } \\
\text { level }\end{array}$ & $\begin{array}{l}\text { Visual communication design, } \\
\text { industrial design, animation } \\
\text { and multimedia design, public } \\
\text { art design and folk art design, } \\
\text { cultural tourism people design, } \\
\text { costume design class, } \\
\text { academic papers and other } \\
\text { eight categories of more than } \\
60 \text { professional categories }\end{array}$ \\
\hline Jin Du award & group & $\begin{array}{l}\text { High school } \\
\text { and college } \\
\text { students }\end{array}$ & $\begin{array}{l}\text { At the } \\
\text { national level }\end{array}$ & $\begin{array}{l}\text { Students of Chinese regions in } \\
\text { the world's largest advertising } \\
\text { campaign }\end{array}$ \\
\hline
\end{tabular}




\begin{tabular}{|c|c|c|c|c|}
\hline $\begin{array}{l}\text { The national } \\
\text { college students } \\
\text { advertising art } \\
\text { competition }\end{array}$ & $\begin{array}{l}\text { The ministry of } \\
\text { education higher } \\
\text { education department }\end{array}$ & $\begin{array}{l}\text { College } \\
\text { students' }\end{array}$ & $\begin{array}{l}\text { At the } \\
\text { national level }\end{array}$ & $\begin{array}{l}\text { National college liberal arts } \\
\text { contest, setting area award }\end{array}$ \\
\hline $\begin{array}{l}\text { Chinese college } \\
\text { students } \\
\text { advertising festival } \\
\text { Academy Awards }\end{array}$ & $\begin{array}{l}\text { China advertising } \\
\text { association }\end{array}$ & $\begin{array}{l}\text { College } \\
\text { students' }\end{array}$ & $\begin{array}{l}\text { At the } \\
\text { national level }\end{array}$ & $\begin{array}{l}\text { Large advertising art college } \\
\text { students activities }\end{array}$ \\
\hline $\begin{array}{l}\text { The One Show, } \\
\text { "golden pencil" }\end{array}$ & The One Club & $\begin{array}{l}\text { Youth } \\
\text { competition } \\
\text { and students } \\
\text { creative } \\
\text { exhibition }\end{array}$ & $\begin{array}{l}\text { At the } \\
\text { national level }\end{array}$ & $\begin{array}{l}\text { The One Club is given the } \\
\text { highest award for top } \\
\text { advertising creative personnel }\end{array}$ \\
\hline $\begin{array}{l}\text { "Star of henan" } \\
\text { design art } \\
\text { competition }\end{array}$ & $\begin{array}{l}\text { The education } \\
\text { department of henan } \\
\text { province, henan } \\
\text { province development } \\
\text { and reform commission, } \\
\text { the cultural department } \\
\text { of henan province }\end{array}$ & $\begin{array}{l}\text { The school } \\
\text { teachers and } \\
\text { students, } \\
\text { design unit, } \\
\text { etc }\end{array}$ & $\begin{array}{l}\text { Provincial } \\
\text { departmental } \\
\text { level }\end{array}$ & $\begin{array}{l}\text { Visual communication design, } \\
\text { industrial design, animation } \\
\text { and multimedia design, public } \\
\text { art design and folk art design, } \\
\text { cultural tourism people design, } \\
\text { costume design class, } \\
\text { academic papers and other } \\
\text { eight categories of more than } \\
60 \text { professional categories }\end{array}$ \\
\hline
\end{tabular}

As you can see from the above art design major practical skills competition schedule, in the artistic design specialized practice skills contest platform is relatively broad, especially advertising art design direction, its contest activity more, effectively build the college students' professional practical platform. For example, the "star of henan" design art competition is "star of the world", "China star", "central star award" series is an important part of the design art competition, has become a unique creative design competition of the central plains and cultural platform. At present, the college students to participate in the Academy Awards, the national college students' advertising art competition, Jin Du award in the province, such as the design of the domestic art competition opportunities is more, but there is few chance to participate in international competition activities.

\section{Practice Skills Contest for Art Design Specialty of Applied Talents Training}

Practical skills competition for students of the main body, from the establishment of topic selection, data collection, analysis and sorting, the formation of the participating copywriting, display and reply to the preliminary final scene, highlight the students' subject position. Professional practice skills contest, therefore, is to help students positioning, for the students' ability to set up a professional platform, at the same time, to promote the teaching reform of art design specialty in colleges and universities to provide the reference.

For art design specialty students build a combat platform. As Chinese college students advertising festival "academy" judge has several years of Beijing industry and commerce university professor zhang said: "very delighted to see entries a year more than a year, year after year. It reflects the overall level of advertising education in our country. Among the results, the Academy Awards. The academy will advertising education at the university of tightly integrated with the enterprise practice, for the advertising education set up a very good practice teaching platform, the academy has done many times in the process of development and innovation to try, for the domestic some new forms, new methods of advertising competition started." As the "academy" one of the earliest review tiger professor at college of communication university of China advertising also said: "entries quality getting better and better, more creative ideas and come, many works can be used directly to customers advertising practice." Art design class, in fact, a lot of practical skills contest, sponsored by the enterprises is the proposition units, such as the national college students' advertising art contest, nestle coffee is proposition unit for many times, let the students begin to contact society, during college contact enterprise, lay a good foundation for future employment. 
To promote the teaching reform of art design specialty in colleges and universities to provide the reference. As we know, in the works of art and design practice, often happen, creatives always stressed: "my works are very creative, designers often complain:" my design is very beautiful, why customers don't appreciate?" But customers often put those "beautiful work" as the garbage into the trash can. This is what people often encounter works of art and design criteria. Art design works a lot of people think that is like "one thousand readers will have one thousand Hamlet", as some people, also some people disdain. In art and design professional teaching, also encountered such a problem, some students works conform to the judgment standard of teacher very much, the usual homework scores high, in the assessment of the final separation, grade teachers in the other teachers, score lower instead. This phenomenon had to let a person thinking, evaluation standard is a navigation, how to promote the reform of art design class teaching to cultivate applied talents for social needs better? And skills contest from the event setup, game design, project evaluation standards and training system match the design and practice of teaching plan, especially the evaluation standards for the construction of practice teaching quality evaluation system, has the very strong era does. Design and operation of such practice skills contest platform to give the team a can see the works of standard, each award involves every aspect of the operation of the art design work of the judges is not only from the school teachers' representative, and units of enterprises from the proposition the delegates and designers from the design company representative. Such a visible criteria, provide the basis for art design specialty teaching reform, provides reference for fostering art design specialty teaching reform.

\section{Skills Contest Platform based on the Practice of Art Design Specialty Teaching Reform}

Italian educationist montessori said: "Tell me, I will forget; show me, I will remember; Involve me, I willunderstand." therefore, art design specialty teaching reform should follow "said to me, I will forget; Show me do, I'll remember; let me in, I will understand" teaching reform, the teaching idea positively, and professional skills contest to promote our deep reflection on the traditional teaching idea and teaching method. Art design class practice skills competition is to encourage, promote and inspection of art design major students' innovative ability and practical application ability of important platform. Based on the platform of the testing standard, with works of art and design students ability of creation and innovation performance. Innovation to improve the students' creative thinking ability, practice ability, must advance the art design specialty teaching reform in colleges and universities, around the central task of teaching reform, strive to cultivate the students' innovation ability to apply, introducing competition mechanism to the reform of teaching, to promote "to promote learning" mode of teaching reform, promote the "four changes" in the teaching reform, in order to realize the target of applied talents training students majoring in arts design.

To promote learning, in order to promote teaching" the establishment of teaching mode. At present, the lack of innovation ability of students is art design professional teaching faces a major problem, mainly displays in the students' practical application ability is poor, work innovation strength is not strong, the practical value is less, the mount guard after graduation at work can't get the role as soon as possible to meet the needs of work, poor adaptability in the job competition, innovation ability is not strong, frequent job-hopping. Rectifying the main reason is that students lack of innovation spirit and the spirit of competition. "All things being the fittest survival", competition is the continuation and development of human beings and all things catalyst. The take-off of the world economy and China's reform of the practice has proved that benefit comes from competition, competition of talent, there is competition is dynamic, there is competition there is development. Thus, competition mechanism is the power source and to promote the development of things. To improve the innovation ability of students and cultivate the students' spirit of competition, the competition mechanism into the art design professional teaching is imperative. In furniture design, for example, the class teaching process, teachers can organize students to set up creative design team first, aims to form a team between competitive, but also for the team, develop the students' team spirit and competitive consciousness. Every creative team is equivalent to a design company, the members 
of each group are the company's employees, occupies an important position in different, bear the different work tasks, while the teacher is the role of the "customer". Every job practice is carried out according to the "customers" demands, important papers due to adopt the proposal form, fair competition, make more (at least 3) to participate in the "customer", according to the "customer" to take an average score is the achievement of the creative design team score, then the creative design team, the CEO of according to the size of the team members contribute to specific to grade, each member in the time of the students' homework at ordinary times. In addition, the completion of each task a specific time, cannot be phased in excess of the prescribed time, is facing "terminate the cooperation contract with the client's risk", that is, the creative design team, the average score is zero. In the finished work, such as the final results of furniture design, Suggestions on display in the form of "exhibition", build a platform of different classes of different grade students learn from each other, and choose a certain number of awards to motivate students. In this way, the introduction of competition mechanism, on the one hand, improve the students' learning enthusiasm, on the other hand, improve the innovative ability of students, and cultivate students' consciousness and team spirit of cooperation, for future employment and lay a good foundation for entrepreneurship.

Practical teaching system is composed of various elements of practice teaching activity overall organic connection, concrete is consists of practice teaching goal system, practice teaching content system, practice teaching system, practice teaching management system and practice teaching quality monitoring system of five subsystems of system. Skills contest is the student actual professional ability of competition, accommodation is a theory in the practice operation skills of the review, for art design specialty construction, participate in large format and introduce professional skills to exercise the student professional ability, recommend the teaching reform and curriculum construction. In the process of practice teaching, how to scientifically evaluate the quality of practice teaching results, how to develop practice teaching standards, is an important problem facing many colleges and universities. And professional skills contest affect colleges and universities is the teaching standard and evaluation standard, it tends to result in the form of hints in routine teaching management, teaching quality monitoring system, teaching evaluation system, etc, have to pay attention to some problems. Will, therefore, is a professional skills contest evaluation standard updates in the practice teaching evaluation standard, can effectively promote the artistic design specialized practice teaching activities better, promote the teaching reform, to better achieve the goal of applied talents training.

\section{References}

[1] L. Bao. To practice skills contest for the platform of practice teaching reform and research for practice teaching reform of financial and economics in - for example. Journal of northeast university of finance and economics, (China 2010), p. 125. (In Chinese)

[2] X. Zhang, N. Fei. Shallow discussion skills contest for the promotion of deepening the reform of practice teaching effect. Education to explore, (China 2008), p. 38. (In Chinese)

[3] Z. Bin. Based on the skills competition under the background of vocational education teaching reform in the direction of research. Journal of adult education, (China 2015), p. 83. (In Chinese)

[4] W. Yan. To strengthen the competition mechanism to improve the teaching quality. Journal of Mengzi teachers, (China 1989), p. 129-130. (In Chinese)

[5] Y. Guo. Practice ability training as the core of practice teaching system construction and practice. Research and exploration on room, (China 2011), p. 325. (In Chinese)

[6] L Zhang. Apparel skills contest leading professional teaching reform thinking and practice. Shandong textile economy, (China 2013), p. 84-85. (In Chinese) 